the electric arc and in her later scientific work, there was no impulsive jumping to conclusions, but patient observation and well-considered reasoning.

Teffont, Salisbury,

$$
\text { A. P. Trotter. }
$$

December 22.

\section{Is the Gulf of Suez a Rift Valley?}

I WAS somewhat surprised when reading Prof. J. W. Gregory's interesting article on "The Structure of the Great Rift Valley "in NATURE of October 6, p. 5I4, to learn that in my lecture to the Royal Geographical Society in I92 I I had thrown doubt on the fault origin of the Gulf of Suez. Fortunately, Prof. Gregory has mentioned the pages in which my views on this subject have been set forth, namely, the Geographical Journal, Vol. 58, pp. 267-27I.

In my paper I considered three areas: (I) the northern portion of the Red Sea proper; (2) the Clysmic Area; (3) the depressions within the Sinai Peninsula parallel to the well-known major one outside it, which includes the Gulf of Aqaba, Dead Sea, and Jordan Valley.

The Clysmic Area is the one which is involved in the discussion. I have defined it as the expanse of lower confused hills and plains which, with the shallow Gulf of Suez, lies between the northern Red Sea Hills, the two Galalas, Ataqa, and Geneffe ranges on the west, and the marked scarps of western Sinai on the east. I have suggested the name "Clysmic" (derived from Clysma, the Roman name for Suez) in order to avoid constantly referring to this wider region (which is really the area under consideration) as the larger Gulf of Suez. In the discussion on this area this statement is made on p. 269. " In this region the more detailed study undertaken over wide portions of the area suggests to me that these surface differences, while emphasised by erosion, are nevertheless based on fault movements." It is true that in the following lines I mention that deeper-seated granitic masses undergoing uplift would produce the effects observed, and that, as in the Red Sea, the minute nature of the elevations in relation to the breadth of the areas makes it difficult to explain the features observed as resulting from tension. But surely this sentence on p. 269 is clear enough: "While the Red Sea might be more purely derived by erosion, there seems no doubt that the Clysmic Area (in which the boundaries with the igneous hill ranges are marked by the most striking faults) is of a fault-controlled type." The italics are mine, added to emphasise the statement.

May I in conclusion give the summary of my views as set forth on p. $27 \mathrm{I}$ of my Geographical Journal article :

"We broadly conclude, in connexion with the present controversy on the rift question, that

"(a) The northern portion of the Red Sea shows no evidence of large faulting, and can be easily explained by erosion of a fold.

"(b) The narrower Clysmic Area is both folded and faulted to a remarkable extent, differing most markedly from the Red Sea region. The boundary between them is marked by a line which prolongs that of the Dead Sea and Gulf of Aqaba depression, on the northern side of which lie the land surfaces of the Clysmic Area and the shallow waters of the Gulf of Suez ( 25 to 40 fathoms deep), while to the south are the several hundred fathom depths of the Red Sea. To this line I specially call attention, though not professing to explain its reason.

"(c) The very narrow valleys in south-east Sinai and presumably the Dead Sea-Jordan depression are obviously fault-controlled in origin, and close study is required to indicate what part tension or compression have played in determining them. Erosion is the cause of the actual valley character."

My impression is that readers of my own remarks will draw quite a different conclusion as to the views I hold from those arrived at by Prof. Gregory.

Prof. Gregory also refers to a reversed fault recorded by me in my " Report on the Oilfields Region of Egypt, I916" (see p. 5I 5). On this point I shall bring comfort to Prof. Gregory and unburden my own conscience. I have long felt that to have one reversed fault in the midst of an area where all are of normal type was extremely unlikely, and I consequently take this opportunity of stating that in the interesting case where the Um Murer Anticline abuts against the ancient metamorphic rocks (see Plate II. of my "Report on the Oilfields Region of Egypt," I9I6) a different explanation will have to be sought.

The locality is somewhat off the beaten tracks, but should one of my colleagues be in the neighbourhood, I would ask him to re-examine the section and give his opinion as to its nature.

It would be a great gratification to me if the International Geographical Congress of 1925 enabled those interested in these subjects to see some of the type sections in the region under discussion. I have unfortunately missed Prof. Gregory on those occasions when there has been formal consideration of these subjects, and I hope the time may be not long delayed ere I meet him in England or Egypt, giving us the opportunity of discussing these questions in that atmosphere of cordial friendship which has so long existed between us.

Geological Survey of Egypt, November 17 .

I AM delighted to learn that Dr. Hume's views and my own are in even closer agreement than I thought, and that I have misunderstood his conclusion as to the relative effects of fold and fault in the formation of the Gulf of Suez. I was unfortunately not able to attend either his lecture to the Royal Geographical Society or his address to the Geological Society. I was influenced by the interpretation of his views by speakers in the discussions, where one of them stated that after the researches of Dr. Hume and his colleagues "we must look elsewhere than in Egypt " for support to the rift valley conception.

The illustrations from the publications of the Egyptian Survey were therefore included in my recent article to correct such misconceptions of the facts. Dr. Hume described that gulf as " one of complicated fold-and-fracture effects," and I was under the impression that he regarded the folds as the main factor, and the gulf as "fault-controlled" but not as faultmade, especially as in the report of his Geological Society address he remarked on the difficulty of "rift formation as defined " by me in a paragraph which seemed to apply mainly to the Clysmic Gulf. The passages quoted in his letter seemed to me, therefore, restricted by some qualifications. But on re-reading both Dr. Hume's paper and address I see that I had read into some sentences more criticism than was intended. Our views as to the Gulf of Suez are therefore in agreement, especially as the representation of the fault at Um Murer as a reversed fault is now placed in suspense as improbable.

I have so often scanned the alluring fault-scarred cliffs on the western shore of the Gulf of Suez through glasses from the sea, that it would be a great joy if the International Geographical Congress of 1925 enabled me to examine them ashore under the guidance of Dr. Hume. 